\title{
Profetas e santidades selvagens. Missionários e caraíbas no Brasil colonial
}

\author{
Cristina Pompa* \\ Doutoranda da UNICAMP e da École de \\ Hautes Études en Sciences Sociales
}

Resumo

$\mathrm{Na}$ batalha pela conquista das almas selvagens, os caraíbas, os grandes xamãs dos Tupinambá, foram considerados pelos missionários como instrumentos do demônio. Ao mesmo tempo, nas fontes quinhentistas e seiscentistas encontramos as categorias de "santidade" ou "profeta", como tradução do termo indígena caraíba. Remetendo os relatos missionários ao contexto histórico e cultural em que se produziram, o artigo tenta identificar o campo semântico a partir do qual o Ocidente evangelizador realizou a leitura e a construção da alteridade indígena. $\mathrm{O}$ "profeta" aparece assim como uma construção negociada: a linguagem religiosa é o terreno de mediação, onde cada cultura, a ocidental e a indígena, encontram o sentido da "diversidade" da outra.

Palavras-chave: indios, xamanismo, missionários

\section{ABSTRACT}

In their battle to conquer Tupinambá souls, early missionaries found their greatest adversaries among the Caraíbas, or great shamans, whom sixteenth and seventeenth-century sources describe as the devil's emissaries. These same sources, however, also employ the terms "holiness" and "prophet" in their translation of the indigenous word "Caraíba". This article seeks to explain this apparent contradiction by placing missionary accounts within the historical and cultural contexts in which they were produced. This allows us to identify the semantic field upon which the evangelizing West based its reading and translation of indigenous "otherness", through the use of religious terms.

Keywords: Indians, shamanism, missionaries 
Poucos fenômenos culturais das terras baixas da América do Sul tiveram tanta fortuna entre os estudiosos de religião indígena quanto o chamado "profetismo tupi-guarani”, cujo tema central consistiria principalmente, mas não exclusivamente, nas migrações "místicas" dirigidas pelos grandes xamãs, ou profetas, em busca de uma terra maravilhosa, onde não seria mais necessário trabalhar, e onde não existiriam nem doença nem morte: a Terra sem Mal'1

Desde as primeiras observações de Nimuendajú, através dos trabalhos de Métraux, até as pesquisas de Pierre e Hélène Clastres, o profetismo tupi-guarani tem sido geralmente considerado como um fenômeno totalmente autóctone, relativo a um sistema cosmológico intrínseco à cultura tupi-guarani como um todo, preexistente à conquista, que se manteve intacto ao longo dos séculos da história do contato como o núcleo mais autêntico do "ser" cultural tupi-guarani. Nos últimos anos, porém, estas teses estão sendo postas em discussão por etnólogos e historiadores, a partir de uma perspectiva que leva mais em consideração o enfoque histórico, perspectiva esta quase ignorada até a década de setenta ${ }^{2}$.

No espaço deste artigo não é possível enfrentar o problema da construção do "profetismo tupinambá" como objeto antropológico ${ }^{3}$. Também, não quero retomar a eterna discussão sobre a anterioridade ou a posterioridade das manifestações "proféticas" à chegada dos brancos, sobretudo porque - colocada nestes termos - a questão não pode ser resolvida. O que interessa aqui é tentar compreender os limites e a função do campo, ou melhor, dos campos semânticos construídos em volta e a partir da noção de "profecia", no contexto do encontro entre indígenas e europeus no Brasil quinhentista e sescentista.

Para uma melhor designação dos conceitos de "profeta" e "profecia" no interior dos códigos religiosos em pauta, vale talvez lembrar alguns momentos decisivos na história de sua construção e utilização. O grego prophetes traduz o hebraico nabi. O sentido original do termo, o de adivinho, especialista da divinação, amplia-se no hebraísmo clássico, designando o "autor inspirado". A profecia hebraica tradicional consiste, na Bíblia, na previsão de calamidades ou na explicação de desastres acontecidos como punições infligidas por Yahweh ao povo de Israel; são estes os chamados "profetas anteriores". Com o colapso final do Reino de Judá e o exílio babilônico, a profecia passa a proclamar, com os chamados "profetas posteriores" (Isaias, Ezequiel, etc.) a próxima instauração de uma nova, perfeita ordem das coisas: o novo Reino, ligando-se à expectativa do Messias. Imbuído, desde o início, da idéia profética da realização do Reino, o cristianismo lê, portanto, a história como história da salvação. A plenitude dos tempos é anunciada no livro do Apocalipse, conclusão cristã da tradição profética de Israel. A etnologia religiosa herda o sentido cristão do termo "profetismo", com o qual indica os movimentos socioreligiosos dos grupos étnicos que projetam 
num futuro escatológico a radical transformação de uma realidade de crise, freqüentemente, mas não necessariamente ligada à situação de domínio colonial.

Voltando ao Brasil do século XVI, acompanhar o iter semântico dos termos "profeta" e "santidade", usados para designar os grandes xamãs, leva-nos a desvendar o processo de leitura e tradução do "outro", que se iniciou com a descoberta, com os primeiros relatos dos viajantes e missionários a respeito dos tupinambá e de seus grandes xamãs: os caraíbas. Com efeito, pretendo aqui refletir sobre o fato de que o "profetismo" é muito mais a projeção de uma categoria ocidental, utilizada na época do contato para ler, entender, e finalmente construir o "outro" indígena, do que propriamente um elemento "original", no sentido de pré-colonial, da cultura tupi-guarani.

A presença de "profetas" e "santidades" em terra de bárbaros e pagãos, em suma, remete a um problema histórico-cultural: o do uso que foi feito destes termos na época dos primeiros contatos, para entender uma alteridade antropológica que a descoberta colocava como dilema. A projeção na humanidade selvagem de categorias tão carregadas de sacralidade no mundo ocidental tinha em primeiro lugar uma função analógico-classificatória (a de "nomear" o outro através de uma linguagem conhecida), mas obedecia também a uma exigência teorética dos missionários de época colonial, portadores de algumas instâncias profético-salvíficas da Idade Média que estava terminando, instâncias que alimentavam as próprias descobertas que estavam acontecendo.

Os antropólogos, encontrando categorias já constituídas nas fontes, as "herdaram", pois além de cumprir a mesma função analógico-classificatória, elas obedeciam também a exigências teórico-metodológicas específicas. Isto não quer dizer que o "profetismo" tupinambá seja apenas uma "invenção" ocidental da época renascentista, "reinventada" pela antropologia no século XX. Pelo contrário, tentarei mostrar como ele constitui um produto cultural original da colônia, fruto do encontro e da tradução recíproca entre escatologia missionária e cosmologia indígena.

Por isso, abordarei a questão da construção do objeto "profeta", ou "santidade", nas fontes quinhentistas e seiscentistas, recolocando-a em seu contexto histórico e cultural para reformular em termos históricos o problema do "profetismo tupi-guarani".

\section{A INVENÇÃO DA AMÉRICA}

As Relações de viagem como fruto do processo de "invenção da América", como diz O'Gorman, já foram e continuam sendo muito estudadas. Basta pensar no próprio O'Gorman, em De Certeau, em Todorov, em Lestringant, em Giucci, só pa- 
ra citar alguns autores fora do Brasil ou, no Brasil, em Laura de Mello e Souza, em Ronaldo Vainfas, em Ronald Raminelli, etc. ${ }^{4}$

Portanto, não constitui nenhuma novidade, hoje, dizer que o indígena descrito nos relatos dos viajantes e missionários é a alteridade radical que a Europa já conhece bem de toda uma literatura clássica, medieval e renascentista. As observações dos cronistas não surgem a partir da realidade indígena, mas, ajudadas pela peculiaridade das culturas nativas, contam algo sobre seu próprio sistema de crenças e valores. Os relatos de viagem, a partir de Colombo, encontram e descrevem apenas o que já conhecem, do Reino do Prestes João ao itinerário teológico, pois a argumentação decisiva não é a prova empírica mas o discurso de autoridade dos eruditos e dos santos. Entre real e imaginário, as imagens e narrativas que os viajantes do século XVI carregam consigo (da Navegatio Sancti Brandani a Il Milione de Marco Polo) fornecem uma imago mundi coerente, sustentada e protegida pelo horizonte teológico. Mesmo quando as imagens oníricas e fantásticas se apagam, a "observação" da realidade continua ocorrendo através da mediação dos esquemas culturais familiares ao observador, mediação esta necessária para organizar e até mesmo para perceber os "fatos", pois a comparação analógica é o único instrumento epistemológico de compreensão cultural.

A famosa análise de Michel de Certeau da Histoire d'un voyage fait en la Terre du Brésil, de Jean de Léry, por exemplo, mostra como a representação histórica se transforma em mise en scène literária pela prática da escrita historiográfica. A narrativa é uma viagem em busca do eu, cujo produto final é a invenção do Selvagem. Na véspera dos tempos modernos, as descrições de Léry inauguram uma série de quadros análogos aos que os relatos de viagem vão apresentar durante quatro séculos.

\section{Povos SEM RELIGIÃO}

No caso específico do domínio do "religioso", as descrições dos viajantes e, sobretudo, dos missionários, são iluminadoras da atitude do ocidente evangelizador diante dos habitantes da Terra dos Papagaios: a descrição dos "selvagens" e de sua religião (ou, melhor, da falta desta) é uma construção que, por um lado, é devida à impossibilidade de reconhecer nos índios o modelo de alteridade religiosa oferecido pelo paganismo clássico e, por outro, é funcional ao projeto catequético.

Com efeito, os cronistas recusam-se a ver fatos de ordem religiosa onde a Escolástica não manda encontrá-los; por isto, os selvagens tupinambás são tão "bárbaros" que não têm religião. Mas, por outro lado, com eles precisa se realizar o desenho divino da pregação do Evangelho aos quatro cantos da terra. Por 
isto, eles são "gentis", na acepção de São Paulo. Ou seja, não são iluminados pela verdadeira fé, mas são passíveis de recebê-la. Entre bárbaros e gentis, entre selvagens e inocentes, entre a ausência de regras morais e a presença de um fundo de humanidade que pode tornar o índio um bom cristão, joga-se a partida da construção do indígena na terra de Santa Cruz.

Entre os tupinambá, os missionários não encontraram nenhum sinal da "idolatria" ou do "paganismo" que eles esperavam e que caracterizava outras regiões do Novo Mundo, como o Peru incaico ou o México asteca: crenças, sacrifícios, ídolos. Nos relatos, não apenas de missionários de diversas ordens religiosas, ou até de diversas confissões, mas também de viajantes leigos, esta ausência de crença, seja mesmo idólatra, junto com a ausência de outros princípios da civilização que até os pagãos têm, é patente.

Já Pero Vaz de Caminha, poucos dias depois do "achamento", declarava que “...eles, segundo parece, não têm nem entendem em nenhuma crença”. Também pouco tempo depois de sua chegada, em sua "informação das terras do Brasil" (agosto de 1549), o padre Manuel da Nóbrega afirmava categoricamente que "esta gentilidad a ninguna cosa adora”. Pero Magalhães de Gândavo, em 1570, e Gabriel Soares de Souza, em 1587, escreviam que os índios não têm "nem fé, nem lei, nem rei". Também para o jesuíta Cardim, "este gentio não tem conhecimento algum de seu Creador, nem de cousa do Céo... e portanto não tem adoração nenhuma, nem ceremonias, ou culto divino"

O cosmógrafo franciscano André Thevet, de volta da experiência na "França Antártica”, assim a descrevia em 1558: “...esta região era e ainda é habitada por estranhíssimos povos selvagens sem fé, lei, religião e nem civilização alguma, vivendo antes como animais irracionais..."”.

Jean de Léry mostrou em várias ocasiões sua aberta simpatia para com os "selvagens", cujas "barbáries" eram bem menores do que aquelas cometidas pelos europeus dilacerados pelas guerras de religião. Contudo, ele teve que reconhecer que é difícil aplicar aos selvagens Tupinambá a famosa sentença de Cícero, de que não há nação tão bárbara e selvagem que não tenha sentimento de uma divindade:

Pois, além de não ter conhecimento do verdadeiro Deus, não adoram quaisquer divindades terrestres ou celestes, como os antigos pagãos, nem como os idólatras de hoje, tais os índios do Peru...Não têm nenhum ritual, nem lugar determinado de reunião para a prática de serviços religiosos, nem oram em público ou em particular"?

As palavras de Léry voltam, praticamente idênticas, quase quarenta anos depois da publicação de sua obra, no relato do capuchinho Claude d'Abbeville, que 
traduz de forma mais articulada o espanto do ocidental (eclesiástico) perante a "falta de religião" entre os Tupinambá:

Não há, penso eu, nenhuma nação no mundo que não tenha uma religião. Todas adoram a um deus, salvo a dos Tupinambá que não adora nenhum, nem celeste nem terrestre, que não idolatra nem o ouro nem a prata nem as madeiras, nem as pedras preciosas nem qualquer outra coisa. Não tinha, até nossa chegada, religião; portanto não tinha sacrifícios, nem sacerdotes, nem ministros, nem altar, nem templos ou igrejas. Nunca souberam os índios Tupinambá o que fosse nem prece nem ofício divino nem oração pública ou particular. ... Não têm culto algum, nem interior nem exterior. $^{8}$

A extraordinária coincidência destas observações, é bom lembrar, depende menos de uma coincidência de fatos observados do que da circulação dos relatos entre os escritores. É patente o caso dos jesuítas, cujas cartas circulavam - de acordo com as indicações do próprio Inácio - em várias traduções, entre a casa geral e as diferentes províncias. Também vale lembrar a longa polêmica entre Thevet e Léry, que conheciam muito bem um a obra do outro, e que por sua vez influenciaram os autores sucessivos, de Montaigne ao próprio d'Abbeville. Todos eles parecem ter atingido uma primeira fonte: a carta de Amerigo Vespucci a 182 Lorenzo de Medici, datada de 1502: "Non tengono né legge né fede nessuna, vivono secondo natura. ... non hanno Re né ubidiscono a nessuno", como também o Mundus Novus: "nullum habent templum et nullam tenent legem, neque sunt ydolatre" ". Vespucci, de fato, foi o primeiro teórico do "estado de natureza" dos selvagens, teoria esta que também influenciou, como veremos, nossos autores.

A coincidência dos relatos dos viajantes revela também o grande debate que estava se travando na Europa a respeito da natureza dos selvagens ou, melhor, do "estado de natureza" deles: tratava-se, de fato, do processo de releitura da identidade ocidental ante as novas humanidades que a descoberta apresentava, através da construção de sua alteridade. O código religioso era, obviamente, o privilegiado na definição da alteridade pela concepção teológica dos missionários. Mas aqui a construção dos outros esbarrava numa dificuldade: os selvagens da terra de Santa Cruz não apresentavam aqueles elementos que encontramos na longa lista de d'Abbeville e que definem o que é a Religião: ídolos, templos, sacerdotes.

A recuperação da antigüidade clássica pela cultura humanista fazia com que a comparação nós-outros se desse em termos de "paganismo": o politeísmo pagão era a dimensão em relação à qual o monoteísmo cristão pensava em si próprio. Por isto, o paganismo (transformado em "idolatria") constituía a necessária linguagem de reconhecimento e de comunicação com as humanidades outras. ${ }^{10}$ 
Isto tinha funcionado na Índia e funcionava no México e no Peru; mas o que fazer da humanidade tupinambá, junto à qual não se encontram os sinais diacríticos da existência de uma "religião"?

A hermenêutica dos viajantes caracterizava então pela ausência o que se apresentava como impossibilidade de identificação de uma presença esperada: se não há ídolos, sacerdotes e templos, não há religião.

\section{Deus, os Selvagens e o fim dos tempos}

Mas este mesmo saber, imbuído de classicidade e Escolástica, entre projeto teológico medieval e cultura humanista, tinha chegado à conclusão, codificada pela Bula Sublimis Deus de 1537, de que os americanos eram homens ("veri homines"), homens "naturais", de acordo com a primeira noção de Vespucci, e como mais tarde Acosta tentará sistematizar na monumental Historia Natural e Moral de las Indias, ao falar em homines sylvestres. Também os homens da natureza - aliás, principalmente estes - precisavam da palavra divina para que se cumprisse a profecia da pregação do Evangelho aos quatro cantos da terra.

Ora, se esta falta de religião facilitava a catequese, eliminando o trabalho de extirpação da idolatria e permitindo trabalhar num terreno virgem, por outro lado a Escolástica mandava identificar no intelecto deste homem "natural" um mínimo sinal da presença de Deus.

Eis, portanto, que quase nas mesmas páginas em que declaram a ausência de religião entre os Tupinambá, os nossos autores apontam para a presença desta noção mínima de Deus entre os selvagens americanos. É uma contradição, não apenas interna aos missionários mas à própria cultura ocidental do século XVI, problema histórico e cultural posto pelo conflito entre o saber garantido pelas certezas da fé e a nova razão "natural", entre os paradigmas medievais e o novo sistema (poder-se-ia dizer "global") que está se construindo a partir da absorção das novas humanidades.

Em vários pontos de sua obra, Thevet, Léry e d'Abbeville lembram a máxima de Cícero (e também a filosofia de Aristóteles, de Tomás de Aquino), segundo a qual não existe povo tão bárbaro que não possua, por instinto, uma mínima noção de divindade. E esta noção se concentra em Tupã, ser mitológico ligado ao céu e ao trovão e, portanto, por analogia, à dimensão celeste do ser supremo da religião judaicocristã.

É por isto que não existe nação tão bárbara que não possua, por instinto natural, uma crença religiosa qualquer e alguma idéia da existência de Deus. [...] No que se refere a este assunto, os selvagens deste lugar mencionam um grande ser, cujo nome em sua língua é Tupã, acreditando que viva nas alturas e que faça chover e trovejar. ${ }^{11}$ 
A analogia é ainda mais clara no discurso jesuítico. Nas mesmas Informações das terras do Brasil, em que declara a falta de crença entre esta "gentilidade", Nóbrega acrescenta que os inacianos, por falta de outro termo para indicar Deus, servem-se justamente do de "Padre Tupana". Cardim se expressa mais ou menos nos mesmos termos, desvelando a pedagogia jesuítica que constrói o Tupã enquanto deus para, a partir dele, elaborar o projeto catequético. A analogia ocasionada pelo caráter urânico de Tupã é a mais patente, mas há outras, como no caso da passagem do apóstolo Tomé ou o conhecimento que os selvagens tinham do dilúvio. Trata-se, aqui, do que Ronaldo Vainfas chama de "hibridismo cultural", derivante da "tradução do catolicismo para o tupi e a tradução tupi do catolicismo". Voltarei a esta questão.

Os Tupinambá, portanto, não tinham religião, mas apenas - como era óbvio em um povo "natural" - uma vaga noção de divindade. O homem natural trazia consigo, em baixo relevo, a possibilidade de uma religião, e de uma religião monoteísta, conforme a teoria da "degeneração" em virtude do isolamento das tribos do Brasil - depois da primeira Revelação.

A bula do papa Paulo III, além de reconhecer-lhes a dignidade de homens, mandava trazer os índios para a fé cristã através da pregação do Verbo de Deus e do exemplo. A imposição da religião dos conquistadores encontrava assim sua plena legitimação, realizando a grandiosa profecia da Conquista: a construção do Reino de Deus na Terra, com um povo virgem.

Aqui está um dos nós conceituais da pregação missionária, nó que, aliás, tinha dirigido teologicamente até a própria "descoberta": o milenarismo cristão.

Muito já foi dito a respeito da visão escatológica e providencialista do próprio Colombo, influenciado pelo meio franciscano ibérico, de tendências joaquimitas. Colombo estava certo de estar realizando a profecia das Sagradas Escrituras, "descobrindo" o novo céu e a nova terra, dos quais fala João no Apocalipse $(21,1)$, e apressando a história do mundo, conforme a promessa de Mateus "Propter electos breviabuntur dies illi” (Mat. 24,22).

Também, vários autores apontaram para o caráter de "fim dos tempos" da pregação no Novo Mundo dos franciscanos, intérpretes das aspirações profético-apocalípticas de uma parte da cristandade perante a reforma. Milenarista era Martin de Valencia, superior dos primeiros doze “apóstolos" franciscanos enviados ao México, como também imbuídos de esperanças escatológicas eram Motolinia (um dos doze) e Mendieta, teorizador dos índios como genus angelicum com que seria possível reconstruir a igreja no Novo Mundo, antes do fim dos tempos. ${ }^{12}$

No Brasil, percebe-se também um clima milenarista; basta pensar na primeira página da Histoire de la Mission, de d'Abbeville, em que o capuchinho 
transcreve a profecia de Mateus: "Et predicabitur hoc evangelium regni in universo orbe, in testimonium omnibus gentibus, et tunc veniet consummatio." Também os outros autores, como Thevet, Léry e d'Evreux, não deixam de mencionar o fim dos tempos e o juízo final, que coincidiria com a pregação da palavra de Deus aos selvagens.

Nos jesuítas, este pendor profético é menos evidente, porque a iminência do Apocalipse não condiz com seu projeto catequético de longo prazo. O grande teórico da alteridade indígena pelo código religioso, Acosta, dedica até sua obra De temporibus Novissimis à exegese do Apocalipse que, para ele, não pode ser considerado tão próximo, já que o simples anúncio do cristianismo a todas as gentes não significa uma verdadeira conquista espiritual à fé cristã. Contudo, se pensarmos na visão edênica de Vasconcelos, que coloca o paraíso terrestre no Brasil, ou no grande intérprete do milenarismo barroco: Antônio Vieira, ou, principalmente, no grandioso projeto das reduções jesuíticas do Paraguai como realização do Reino de Deus na terra, aparece claro que os inacianos também foram sensíveis às instâncias proféticas que animaram a conquista espiritual do Novo Mundo.

A necessidade, filosófica e teológica, de atribuir aos índios umas crenças, mesmo se vagas ou errôneas, obedecia a uma exigência cultural de "ler" o outro e traduzi-lo e, por outro lado, traduzir o "eu" para o outro. Para isto era necessário construir uma linguagem de mediação. No início da Idade Moderna, o código prioritário de leitura e interpretação da realidade, inclusive das alteridades antropológicas, ainda era o religioso; este último englobava todos os outros: o moral, o político, o filosófico (lembre-se a justaposição de fé, lei e rei). Ou seja, qualquer manifestação social da alteridade que a descoberta apresentava era lida sub specie religionis e traduzida na linguagem religiosa

A oposição irredutível presença/ausência de religião, que impossibilita qualquer tipo de mediação retrocedendo na esfera da não-humanidade os selvagens americanos, transforma-se no binômio verdadeira/falsa religião. A partir daí é possível a comunicação e, portanto, a obra de catequese dos selvagens.

\section{MissionáRios E PROFETAS}

A leitura do outro via código religioso se encaminha desse modo, em trilhas mais conhecidas e percorríveis: a religião do mundo clássico é o referente privilegiado no encontro com as "religiões" ameríndias. E como a primeira sistematização teológica cristã tinha elaborado a noção de "paganismo" a partir da oposição verdade-falsidade, a mesma teologia é projetada nas leituras da religião nativa, que existe, in nuce, mas que é falsa, fruto da manipulação diabólica. É 
de fato o Diabo, o rei da mentira, que falsifica e corrompe as puras imagens da fé para conquistar as almas dos índios.

Eis, então, o grande antagonista do projeto missionário em terra americana, incontrastável senhor das almas dos pobres índios: o Demônio. Muito já foi escrito sobre a preeminência da chave de leitura demonológica na interpretação dos indígenas do Brasil, fartamente utilizada na literatura quinhentista, principalmente missionária; assim, não me deterei mais aqui sobre esta questão. Basta lembrar que de Thevet a Léry, de frei Vicente de Salvador a Nóbrega, de d'Abbeville a Vieira, todos os homens de fé dos séculos XVI e XVII apontam para o senhorio do Maligno sobre os índios.

Este domínio do Demônio sobre os indígenas se manifesta de uma forma bem precisa: através dos grandes xamãs, os pajés ou caraíbas, que as fontes chamam, obviamente, de feiticeiros e, menos obviamente, de "santos", "santidades" ou, finalmente, de "profetas". Na falta de outros sinais de idolatria, são estas extraordinárias personagens, das quais as fontes não ignoram nem minimizam o poder, os intermediários entre o Diabo e as almas selvagens.

Desde o princípio, os missionários identificam nos caraíbas os inimigos mortais da catequese e, por conseguinte, seus "maiores contrários", para usar as palavras de Nóbrega. São eles que, com suas "cerimônias diabólicas", impedem os índios de se aproximarem da verdadeira fé. São eles que convencem os índios de que o batismo praticado pelos padres provoca doença e morte (o que, em época de grandes epidemias e de batismo in articulo mortis não é difícil). São eles que organizam levantes e fugas dos indígenas das aldeias. São eles que conduzem as grandes migrações em busca de novas terras, talvez de "terras da imortalidade", como diz Gândavo. Enfim, são eles que se opõem com toda a sua força e poder diabólico ao grande desenho catequético de marca escatológica, vale dizer, à realização do grandioso projeto do Reino de Deus na Terra, com o genus angelicum dos índios.

Os inacianos são claríssimos em imputar ao Demônio a ação dos feiticeiros que, porém, não se incomodam em chamar de "santidades", embora tenham quase sempre o cuidado de apontar para a sua falsidade. Na mesma página dos Tratados citada acima, Cardim declara:

Entre elles se alevantarão algumas vezes alguns feiticeiros, a que chamão caraíba, Santo ou Santidade, e é de ordinario algum Indio de ruim vida: este faz algumas feitiçarias e cousas estranhas á natureza, como mostrar que ressuscita a algum vivo que se faz morto, e com esta e outras cousas similhantes traz após si todo o sertão.

Nas Informações das terras do Brasil, Nóbrega também fala das Santidades: 
De certos en certo años vienen unos hechizeros de luengas tierras, fingiendo traer sanctidad e al tempo de su venida les mandan a alimpiar los caminos e van los a recebir con danças y fiestas según su costumbre... y otras cosas semejantes les dize y promete, con que los engaña; de manera que creen haver dentro en la calabaça alguna cosa santa y divina, que les dize aquellas cosas, las quales creen. ... Estos son los majores contrarios que acá tenemos, y hazen crer algunas vezes a los dolientes que nosotros les metemos en el cuerpo cuchillos, tigeras y cosas semejantes, y que con esto los matamos. ${ }^{13}$

O texto de Nóbrega é particularmente interessante porque permite desvendar também um fragmento da hermenêutica do "outro". Com efeito, ao acusar os padres de matar os doentes através de objetos inseridos no corpo, os Tupinambá mostram sua leitura da atitude jesuítica no interior de seu próprio sistema de sentido, isto é, em termos de xamanismo.

Passando às outras testemunhas missionárias, que no início da colônia são quase que exclusivamente francófonas, notamos que o termo que traduz para o francês pagé ou caraíba é o de prophète, profeta.

André Thevet intitula o cap. XXXVI das Singularidades: "Dos falsos profetas e magos desta terra, os quais se comunicam com os espíritos malignos." $\mathrm{Na}$ Cosmographie Universelle, ele transcreve o mito do herói civilizador, MaireMonan, um grande caraíba (em outras fontes seu nome é Sumé, ou Zumé, o mesmo que os jesuítas identificaram com São Tomé), do qual ainda se conservam as pegadas numa pedra. A remoção desta pedra está ligada à catástrofe que destruirá o mundo. Assim conclui o franciscano: "Voila la doctrine de laquelle ces Caraibes ont repeu ce simple peuple...lesquel estoient jadis grandes Necromantiens, et sont encore invocateurs des diables. ${ }^{14}$

A descrição dos rituais dos caraíbas, feita por Jean de Léry, e sua assimilação ao sabá, é tão famosa e citada que não é preciso propô-la novamente aqui. Vale lembrar apenas que em Léry, também, o termo usado é "profeta". A comparação bíblica esclarece as características destes profetas tropicais:

"Esses trapaceiros, em suma, nos aborreciam tanto quanto os falsos profetas de Jesabel que odiavam ao profeta Elias, denunciador de seus abusos."'15

O companheiro de Claude d'Abbeville, Yves d'Evreux, intitula um capítulo inteiro de sua obra: "Como fala o diabo aos feiticeiros do Brasil, suas falsas prophecias, idolos e sacrificios." ${ }^{16}$ Nele, o capuchinho não nega "verdade" às obras dos grandes feiticeiros, mas, através de muitas citações das Escrituras e dos Padres da Igreja, mostra que se trata de obras do Maligno.

Santos, santidades, profetas. Nem sempre os religiosos lembram de esclarecer o caráter de falsidade desta qualidade. Por que, então, os missionários apli- 
cam aos feiticeiros os termos que, em sua cultura, pertencem à esfera do sagrado?

Ronaldo Vainfas enfrenta este problema, com relação ao termo "santidade", a partir das observações de Laura de Mello e Souza sobre a fluidez das fronteiras entre Deus e o Diabo no imaginário (principalmente popular) no início da época moderna, em que freqüentemente a santidade é apenas a falsa aparência da natureza demoníaca. Assim, os missionários trouxeram para a América os dilemas religiosos de uma época em que a necessidade de separar o santo do diabólico era a verdadeira obsessão de inquisidores e teólogos. Este contexto foi rapidamente projetado nos discursos sobre os índios, e neste contexto tem que ser enquadrado o uso do termo "santidade" para indicar as "cerimônias diabólicas" dos caraíbas. ${ }^{17}$

Na mesma direção de Vainfas, podemos acrescentar alguns elementos, úteis talvez para esclarecer esta "fronteira incerta" entre o divino e o demoníaco na cultura ocidental que se debruça sobre a alteridade americana.

Em primeiro lugar, vimos que os missionários encontram-se diante da necessidade epistemológica de atribuir aos "outros" uma religião, e a exigência prática de estabelecer com esta um diálogo na base da oposição verdade/falsidade. Estas exigências levam à elaboração de uma linguagem que possa dar conta, ao mesmo tempo, da realidade falsa (construída pelo Demônio) e da verdadeira, revelada por Deus e veiculada pelos padres. Vale lembrar, neste sentido, que a Patrística condena a feitiçaria porque falsa, não enquanto ineficaz, mas enquanto eficaz a partir da distorção diabólica do mundo natural. Este aspecto é bem expresso, como vimos, por d'Evreux.

Eis, portanto, que os feiticeiros são os "santos" dos outros e seus embustes são "como dizer coisa divina". É no conflito radical entre a realidade falsa dos feiticeiros e a verdadeira dos padres que podemos acompanhar esta confusão de horizontes devida à utilização de uma linguagem comum.

Francisco Pires, em carta de 1552, relata um sermão de Nóbrega numa aldeia indígena: "diziéndoles el padre que aquella era verdadeira santidad, y diziendo a los principales que se aparjassem para las cosas de nuestro Señor, de parte del Obispo, que era el verdadero 'Pajé-Guaçu', que quiere dezir "Gran Padre”"1.

Há também outras testemunhas desta "batalha pelo monopólio da santidade", segundo a feliz expressão de Vainfas. Assim, por exemplo, o padre Azpilcueta Navarro inflamava os índios em suas pregações nas aldeias do sertão:

começava a despejar a torrente da sua eloquência, levantando a voz e pregando-lhes os mistérios da fé, andando em roda deles, batendo o pé, espalmando as mãos, fazendo as mesmas pausas, quebras e espantos costumados entre seus pregadores, para mais os agradar e persuadir ${ }^{19}$. 
Da mesma forma, Pero Correa, ainda irmão, relata as indicações precisas recebidas pelo padre Leonardo Nunes em suas pregações nas aldeias: "Por todos os lugares e povoações que passavamos me mandava preguar-lhe nas madrugadas duas horas ou mais; e era na madrugada porque emtão era custume de lhe preguarem os seus Principaes e Pagés a que elles muyto creem.. ${ }^{20}$

Não se trata de iniciativas autônomas, mas da pedagogia jesuítica clássica que se utiliza de elementos da cultura nativa como "linguagem" para veicular conteúdos da fé católica, na mesma linha da utilização do nome Tupã para indicar Deus, ou Jeropari e Anhã para o Diabo, e assim por diante. Sem dúvida, nesta apropriação de certas características dos caraíbas, jogou um papel fundamental a questão do poder. Ou seja, a "batalha pelo monopólio da santidade" foi uma luta mortal pelo poder espiritual, em que os rivais tentaram se apoderar dos instrumentos, dos símbolos, da fala dos outros. Neste sentido, é esclarecedor o exemplo do padre Francisco Pinto, que ficou conhecido entre os potiguaras do Rio Grande do Norte - que ele evangelizou no final do século XVI - como Amanaiara, "senhor da chuva", como eram os caraíbas e, como os dos caraíbas, seus ossos se tornaram objeto de culto entre os índios ${ }^{21}$.

Há, então, uma sobreposição entre caraíba e missionário procurada, como vimos, pelos padres, mas também construída do lado indígena no esforço de atribuir sentido à nova realidade colonial. Basta pensar na leitura em termos xamanísticos da atitude dos jesuítas, relatada por Nóbrega. É bom lembrar também que o nome caraíba foi dado aos brancos (e este nome ainda hoje os designa em muitas regiões do Brasil) enquanto categoria de alteridade, talvez indicando os heróis culturais cujo retorno tinha sido prometido pelos mitos.

Mas não é tudo. As "santidades" indígenas apropriaram-se não apenas dos signos exteriores, como também da fala dos padres católicos, certos de poder exercer o ministério sacerdotal. O trecho seguinte, tirado da Relação do jesuíta Fernão Guerreiro (1600 a 1609), relata a chegada de uma santidade numa aldeia em que se encontra um padre. Trata-se de um exemplo extraordinário da situação simbolicamente "híbrida", na qual a fronteira entre "eu" e "outro" (e, do lado missionário, entre "lícito" e "ilícito") torna-se sutil e confusa:

Sairam-no todos a recebelo com diligencia e aí começou a entoar uma ravia, de que nada lhe entendemos e cuido que eles mesmos lhe entende, e isto falando ele e respondendo-lhe os outros à maneira de clérigos que rezam coro. Eu também saí de casa três ou quatro passos. Ele estava como quem ensina a doutrina, misturando mil desbarates, como era dizer Santa Maria, tupana, remireco, que quer dizer Santa Maria, mulher de deus, e outros despropósitos semelhantes. Estava posto de joelhos, com os olhos no céu e as mãos levantadas e abertas como sacerdote que diz missa....Ao dia seguinte me pediu audiencia, saimos ao terreiro, mandei falar um in- 
dio nosso principal. Mas respondeu com contar de sua santidade, mas foi tão prolixo que lhe disse eu que não vinha a ser ensinado nem dos seus, senão para lhe ensinar o caminho do céu e que para isso os queria levar para a igreja. ${ }^{22}$

Logo, estamos perante a leitura da alteridade religiosa nos termos que o horizonte simbólico de cada cultura oferece: neste sentido, a "santidade" para designar os feiticeiros é o oposto especular do termo caraíba para indicar os brancos. Da mesma maneira, na situação colonial, o caraíba Sumé dos Tupinambá é o São Tomé dos missionários. Se o grande caraíba mitológico é o grande santo da tradição católica, não há de estranhar que os caraíbas contemporâneos sejam "santos".

Quanto ao profeta, poder-se-ia dizer, de antemão, que o termo parece em muitos casos utilizado mais no sentido grego (prophetes) de "adivinhar o futuro" através de oráculos, do que propriamente no sentido bíblico de instrumento de Revelação ao povo de Deus. As fontes concordam em frisar o fato de que o caraíba "diz o futuro" a respeito da saúde e da guerra, com a ajuda dos maracás $^{23}$. Esclarecedora é a passagem de Thevet que define os caraíbas como adeptos da nigromancia, mostrando claramente, e mais uma vez, a negativização da prática pagã, neste caso a oracular, operada pelo cristianismo: quem prediz o futuro fora do modelo bíblico e cristão da "profecia" e da "visão mística" é nigromante, evocador do Diabo.

Propõe-se de novo aqui a dicotomia verdade/falsidade já apontada para o termo "santidade", dicotomia que ganha profundidade a partir de toda a tradição bíblica e cristã dos "falsos profetas", anunciando a vinda do Anticristo na véspera do fim dos tempos. Trata-se exatamente daquela vertente milenarista do cristianismo, imbuída da tradição profética vetero-testamentária e da apocalíptica joanina, até Gioacchino da Fiore, que foi mantida por uma parte dos intelectuais cristãos e teve um momento de grande auge justamente no século XVI.

Esta tradição profética, trazida para o Novo Mundo, se apresenta freqüentemente nos autores que estamos examinando. Já vimos, por exemplo, os versículos de Mateus sobre o fim do mundo no texto de d'Abbeville. Podemos acrescentar aqui que no texto de d'Evreux está claramente dito que a viagem dos capuchinhos e a conversão do gentio da ilha do Maranhão foram profetizadas por santos inspirados pelo Espírito Santo (e aqui está a marca joaquimita) e por Isaías e Sophonia.

Igual "profecia" é atribuída por Thevet aos próprios caraíbas. Depois de ter relatado a comunicação entre caraíbas e l'esprit, ou seja, o Demônio, ele comenta: "Je ne passeray aussi plus outre sur la dispute, si le diable sçait et cognoist les choses futures....Mais un cas vous diray-je bien, 


\section{que long temps avant que nous y arrivassions l'esprit leur avoit predit nostre venue." ${ }^{24}$}

Por sua parte, Léry põe na boca de um velho índio as seguintes palavras:

(...) há muito tempo, já não sei mais quantas luas, um mair como vós, e como vós vestido e barbado, veio a este país e com as mesmas palavras procurou persuadirnos a obedecer a vosso Deus; porém, conforme ouvimos de nossos antepassados, nelle não acreditaram. Depois dêsse veio outro e em sinal de maldição doou-nos o tacape com o qual nos matamos uns aos outros ${ }^{25}$.

Léry relaciona estas palavras com a tradição cristã da pregação do Evangelho às extremidades do mundo antes do Juízo Final; também o huguenote lembra um trecho do Apocalipse para explicar a presença dos dois "profetas": o verdadeiro, no qual os homens não acreditaram, e o falso, que os levou à perdição. Vale lembrar, também, que Mair é o nome com que os tupinambás designavam os franceses. O termo parece ter vivido a mesma "aventura semântica" de caraíba: Maira é um herói cultural da mitologia tupi, cujas ações são, em outras versões, atribuídas a Sumé, justamente um grande Caraíba.

Está claro aqui o jogo de espelhos que se estabelece entre padres e caraíbas, entre verdadeiros e falsos profetas, entre profecias cristãs sobre pregação aos gentios e profecias nativas sobre a chegada dos brancos. Mais do que a uma coincidência de mitologias, estamos dinate do problema epistemológico da compreensão e, portanto, da tradução das alteridades antropológicas no interior do quadro de uma história preestabelecida, de um e de outro lado: pelo mito do herói cultural e pela história da salvação. Isto leva a uma curiosa coincidentia oppositorum, que se expressa através de uma linguagem comum.

As "santidades" e os "profetas" indígenas são, por conseguinte, uma construção negociada. A linguagem religiosa parece tornar-se o terreno de mediação onde cada cultura pode tentar ler a diversidade da outra e onde a alteridade pode encontrar seu sentido e, portanto, sua "tradução" em termos culturalmente compreensíveis. Apenas no interior deste campo semântico me parece possível colocar corretamente e, diante disso, tentar interpretar o problema histórico e cultural posto pelos profetas tupinambás.

\section{NOTAS}

\footnotetext{
* Este trabalho faz parte de uma pesquisa maior em andamento, que conta com o apoio da Fapesp.
}

${ }^{1}$ Entre as obras "clássicas" sobre o profetismo tupi-guarani e o mito da "Terra sem Mal", encontramos: Nimuendajú, Curt. "Die sagen von der Erschaffung und Vernichtung der Welt als Grundlagen der Religion der Apapocuva-Guarani”. In Zeitschrift für Ethnologie. Berlin, 1914, 46, pp. 287-399; MÉTraux, Alfred. Migrations historiques des tupi-guarani. Paris, Librarie Orientale et Américaine, 1927; Id. La religion des tupinambás. Paris, 1928 (Ed. bras.: São Paulo, 1950); SCHADEN, 
Egon. A mitologia heróica de tribos indígenas do Brasil. Rio de Janeiro: MEC, 1959; PereirA DE QueIroz, Maria Isaura. O Messianismo no Brasil e no mundo. São Paulo: Dominus, 1965; Clastres, Hélène. La Terre sans Mal. Le prophétisme tupi-guarani. Paris: Seuil, 1975.

${ }^{2}$ Cf. MeliÁ, Bartomeu. El guaraní conquistado e reducido. Asunción: Biblioteca Paraguaya de Antropologia, 1988; Id.”La tierra sin mal de los guaraní: economía y profecía”. In América Indígena. México, 1989, vol. XLIX; FAusTo, Carlos. "Fragmentos de História e Cultura tupinambá". In História dos Índios do Brasil (org. M. Carneiro da Cunha). São Paulo: Fapesp/SMC: Companhia das Letras, 1992, pp. 382-396; Monteiro, John M. "Os guarani e o Brasil meridional” In História dos Índios do Brasil, Op. cit., 1992, pp. 475-498; VAINFAS, Ronaldo. A heresia dos Índios. Catolicismo e rebeldia no Brasil Colonial. São Paulo: Companhia das Letras, 1995.

${ }^{3} \mathrm{~A}$ análise completa da história dos estudos, a partir deste ponto de vista, encontra-se em outro trabalho (PoMPA, Cristina. "O mito do Mito da Terra sem Mal: a literatura 'clássica' sobre o profetismo tupi-guarani”. In Revista de Ciências Sociais, Fortaleza, 1998, vol. XXIX, nºs 1 e 2, pp. 44-72).

${ }^{4}$ O'Gorman, Edmundo. A invenção da América. São Paulo: Unesp, 1992 (1 $1^{\mathrm{a}}$ Ed. Buenos Aires, 1958); De CerTEAu, Michel. L'écriture de l'histoire. Paris: Gallimard, 1975; Todorov, Tzvetan. La conquête de l'Amérique. La question de l'autre. Paris: Seuil, 1982; em LeSTRINGANT, Frank. L'atélier du cosmographe ou l'image du monde à la Renaissance. Paris: Albin Michel, 1991; em Giucci Guillermo. Viajantes do Maravilhoso. O Novo Mundo. São Paulo: Companhia das Letras, 1992; MeLLo E SouZA, Laura. Inferno Atlântico. Demonologia e colonização. Séculos XVI-XVIII. São Paulo: Companhia das Letras, 1993; RAmineLLI, Ronald. Imagens da colonização. A representação do Índio de Caminha a Vieira. Rio de Janeiro: Zahar; São Paulo:EDUSP/Fapesp, 1996.

${ }^{5}$ Caminha Pero Vaz de. "Carta de Pero Vaz de Caminha".In Pereira Paulo Roberto (org.) Os três únicos testemunhos do descobrimento do Brasil. Rio de Janeiro: Lacerda Editores, 1999, p. 54; NóBREGA, Manuel da SJ- "Informação das terras do Brasil" (carta aos padres e irmãos de Coimbra; Bahia, agosto (?) de 1549). In LEITE, Serafim. Cartas dos Primeiros Jesuítas no Brasil (1538-1553). São Paulo: Comissão do IV Centenário da Cidade de São Paulo, 1954, vol. I, p. 150; Gandavo, Pero de Magalhães. - Tratado da terra do Brasil - História da província de Santa Cruz. Belo Horizonte: Itatiaia, 1980. (1 $1^{a}$ publ. do Tratado: 1826; $1^{a}$ publ. da História: 1576); SouZA, Gabriel Soares de. Tratado Descritivo do Brasil. São Paulo: Companhia Editora Nacional, 1971 (1584); CARDIM, pe. Fernão S.J. Tratados da terra e gente do Brasil. São Paulo: Companhia Editora Nacional, 1978 (1625), p. 102.

${ }^{6}$ Thevet, André. As singularidades da França Antártica. Trad. Eugênio Amado. São Paulo: EDUSP; Belo Horizonte: Itatiaia, 1978, p. 98 (Les singularitez de la France Anctartique, autremment nommee Amerique...Paris: Maurice de la Porte, 1557).

${ }^{7}$ LÉRY, Jean de. Viagem à terra do Brasil. Trad. Sérgio Milliet. São Paulo: Livraria Martins Editora, 1960, p. 185, (Histoire d'un voyage faict en la terre du Brésil... La Rochelle: A. Chuppin, 1578).

${ }^{8}$ D’AbBeville, Claude OFM. História da Missão dos Padres Capuchinhos na llha do Maranhão e terras circunvizinhas. Trad. Sérgio Milliet. São Paulo: EDUSP; Belo Horizonte,Itatiaia, 1975, p. 251 (Histoire de la Mission des Peres Capucins en I'Isle de Maragnon et terres circumvoisines. Paris: Huby, 1614).

${ }^{9}$ Vespucci, Amerigo. "Nota d'una lettera venuta d'Amerigo Vespucci a Lorenzo di Piero Francesco de' Medici l'anno 1502 da Lisbona della loro tornata delle nuove terre...” In GASBARRO, Nicola (org.) 1492: ... apparve la terra, Milano, Giuffré, 1992, p. 124; id. Mundus Novus. In Firpo, Luigi (org.). Colombo - Vespucci - Verrazzano. Torino: Einaudi, 1965, p. 88. 
${ }^{10}$ Para este aspecto cf. Bernand, Carmen e Gruzinski, Serge. De l'idolâtrie. Une archéologie des sciences religieuises. Paris, Seuil 1988. Uma exposição mais aprofundada do uso da categoria do "paganismo" e da "idolatria" como linguagem universal de objetivação da alteridade encontrase em SABbatucci, Dario. Sommario di storia delle religioni. Roma, Il Bagatto 1991, p. 65 e ss. e, sobretudo, em GASBARRO, Nicola. II linguaggio dell'idolatria, op. cit.

${ }^{11}$ TheVet, Op. cit. p. 99.

${ }^{12}$ Cf., entre outros, Batalllon, Marcel. "Novo Mundo e Fim do Mundo". In Revista de História. São Paulo, pp. 343-351, 1954, V (18); PHELAN, John. The millennial kingdom of the Franciscans in the New World. Berkeley: University of California Press 1970; Prosperi, Adriano. "America e Apocalisse. Note sulla 'Conquista spirituale' del Nuovo Mondo”. Critica Storica, Roma, XIII (1), pp. 1-61; 1976, Delumeau, Jean. Mille ans de bonheur. Une histoire du paradis. Paris: Fayard, 1995.

${ }^{13}$ NóBreGA, Op. cit., p.150.

${ }^{14}$ Thevet, André. La cosmographie universelle d'André Thevet cosmographe du roy. Tome II in Les français en Amérique - Le Brésil et les Brésiliens. Paris: Presses Universitaires de France, 1953 (1575) Introduction par Ch.-André Julien, p. 60.

${ }^{15}$ LÉRY, op. cit., p. 195.

${ }^{16}$ D’Evreux, Yves OFM - Viagem ao Norte do Brasil. Trad. Cesar Augusto Marques (1874) Rio de Janeiro: Livraria Leite Ribeiro, 1929 (Voyage dans le nord du Brésil, Paris, Franck, 1864).

${ }^{17}$ VAINFAS, Op. cit., pp. 62-63.

${ }^{18}$ Pires, Francisco. "Carta dos meninos órfãos ao Padre Pero Domenech, Lisboa” (Bahia, 5 de agosto de 1552). In LeITE, Op. cit., p. 386.

${ }^{19}$ VAsconcelos, Simão de. Crônica da Companhia de Jesus. Petrópolis: Vozes, 1977 (1663), vol. I, p. 221.

${ }^{20}$ CORrÊA, Op. cit., p. 220.

${ }^{21}$ Cf. Figueira, Luis. Relação do Maranhão (1608). Introdução, notas e comentários de Thomaz Pompeu Sobrinho. In Três documentos do Ceará colonial. Fortaleza: Departamento de Imprensa Oficial. 1967, p. 107.

${ }^{22}$ Guerreiro, Fernão. Relação anual das coisas que fizeram os padres da Companhia de Jesus nas suas missões nos anos de 1600 a 1609. Coimbra: Imprensa da Universidade, 1929.

${ }^{23}$ Os maracás foram os únicos objetos assimilados pelos missionários aos ídolos, constituindo portanto os únicos sinais da "idolatria" indígena.

${ }^{24}$ Thevet, Cosmographie, Op. cit., p. 82.

${ }^{25}$ LÉRY, Op. cit., p. 196.

Artigo recebido em 10/1999. Aprovado em 09/2000. 